\title{
ENGINEERING GEOLOGICAL BEHAVIOUR OF VOLCANIC FORMATIONS. REFERENCES TO INSTABILITY PHENOMENA AND TOWN PLANNING IN LESVOS ISLAND, GREECE.
}

\author{
Saroglou H. ${ }^{1}$ \\ Engineering Geologist, M.Sc., PhD \\ Geotechnical Dept., School of Civil Engineering, National Technical University of Athens, \\ 7-9 Iroon Polytechniou Str., 15780, Zografou. tel. 210 7722440, e-mail: saroglou@central.ntua.gr
}

\begin{abstract}
The volcanic formations have varying behaviour between rock and soil depending on their geological origin, weathering degree and fracturing degree. The engineering behaviour and weathering classification of these formations is briefly reviewed. Slope stability problems in these rocks have either the form of soil type instabilities (mainly circular failures and creep phenomena) or rock instabilities such as rock sliding on discontinuities and rockfalls. These slope instabilities pose significant problems to human activities.

A case study referring to slope stability problems in different volcanic formations is given from the area of Petra municipality in Lesvos Island, Greece. The main volcanic formations in the study area are rhyodacitic and latiandesitic lavas, having rock behaviour and perlites, silicated lavas and pyroclastics, which have a soil like behaviour. Additionally, profiles of totally weathered andesites resulting to clay rich soils are frequently encountered. The mechanism of the anticipated instability phenomena are presented and analyzed.

Finally, a simple vulnerability map for instabilities was prepared, which can assist in town planning. Based on the field observations, the potential for occurrence of instability phenomena is related to the following factors: a) Slope aspect and b) geological nature of volcanic rocks (weathering degree and permeability).
\end{abstract}

Keywords: Slope stability, weathering, andesites, rockfall.

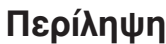

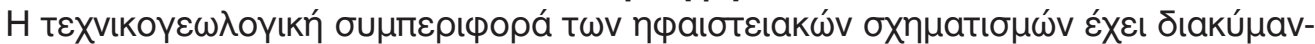

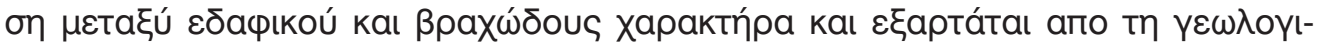

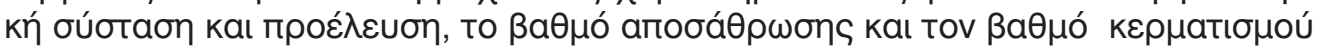

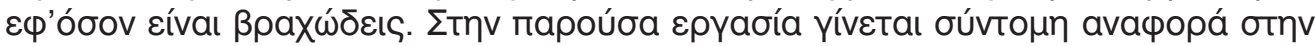

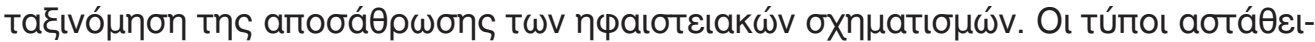

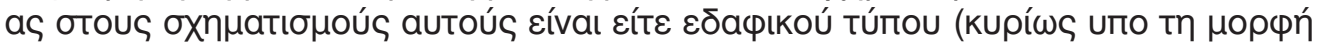

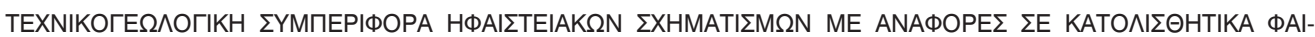

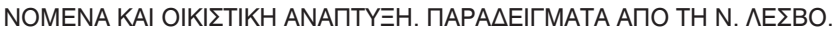

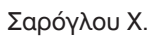




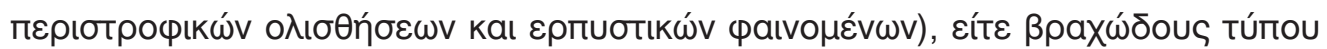

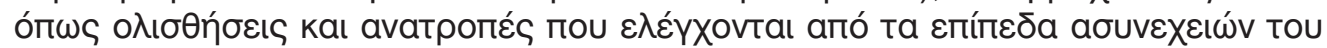

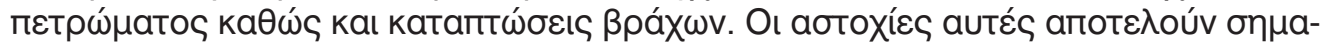

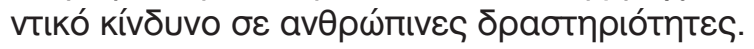

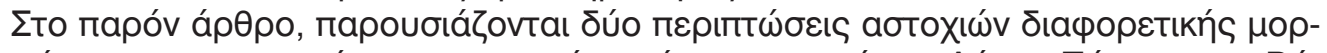

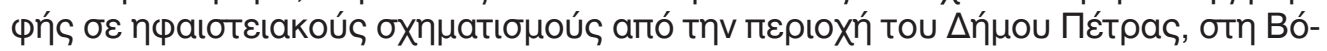

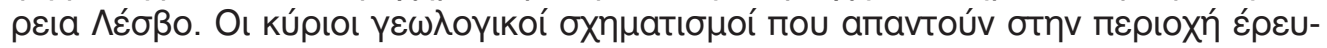

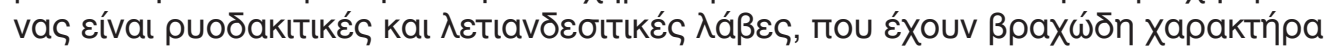

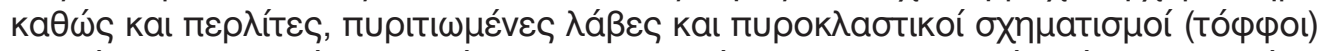

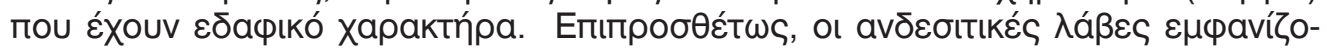

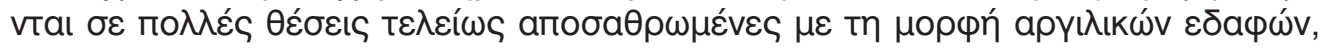

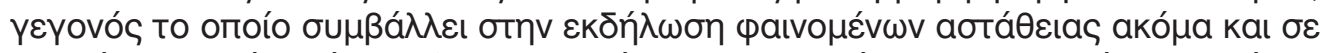

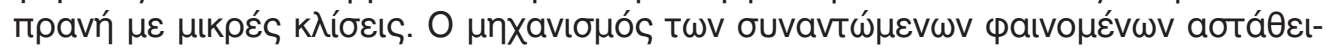

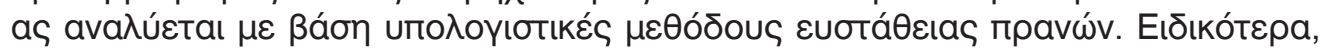

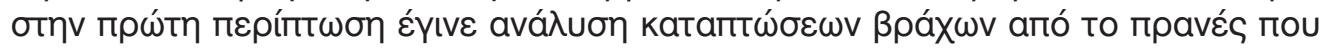

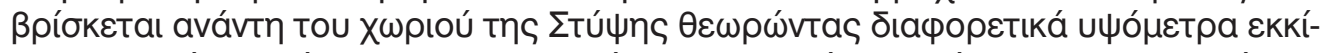

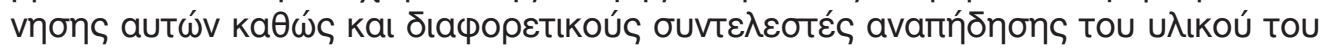

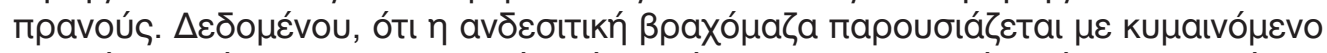

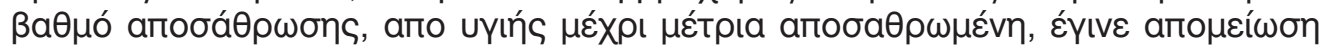

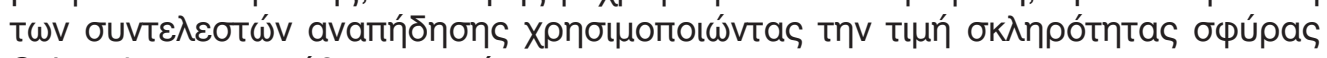

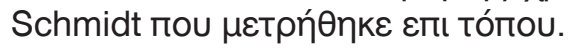

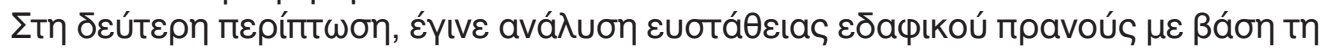

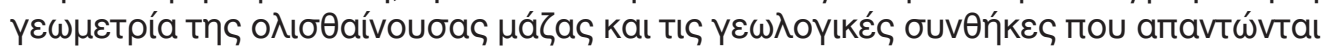

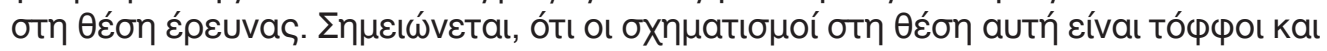

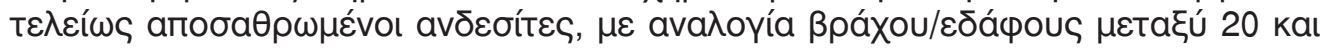

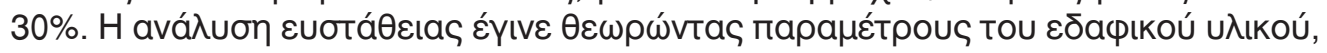

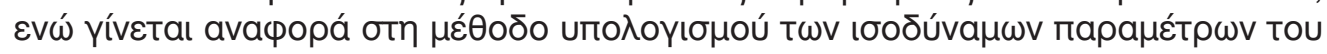

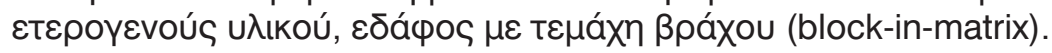

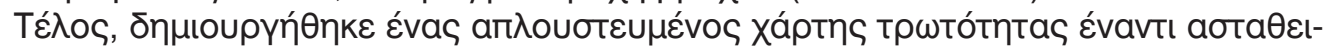

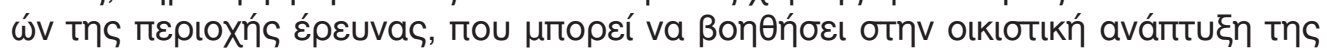

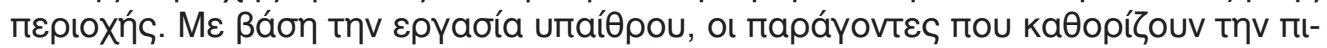

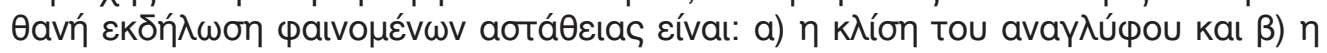

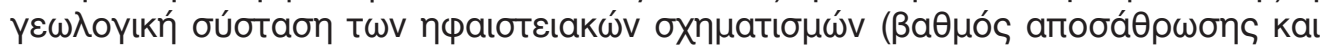
пврато́тпта).

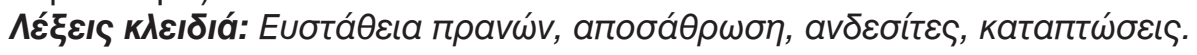

\section{Introduction}

\subsection{Engineering behavior of volcanic formations}

Volcanic formations originate from volcanic eruptions or magma flow. Their composition may differ significantly according to the chemical composition of the magma (mafic, felsic) and the hydrothermal alteration. Usually, the change of mineral structure due to weathering in- creases with the weathering degree and finally the rock is altered to soil. In some cases, complete weathering profiles are encountered in volcanic rocks. The properties of the volcanic formations and their long-term behaviour in slopes are strongly controlled by the degree of weathering (soil and rock proportion in the mass) and the mineralogy of clay components when totally weathered (Irfan, 1999). 
Compared to the work on granitic and metamorphic rocks, the studies carried out on the weathering of volcanic rocks are considerably limited. Saito (1981) studied the relationships between the physical and mineralogical properties of weathered igneous rocks, including andesites, to define a quantitative measure of the degree of weathering. Tugrul \& Gurpinar (1997) studied the basalts at Niksar (Turkey) and proposed a weathering classification consisting of four (4) main classes and seven sub-classes ranging between fresh rock (class I) and soil (class IV). Emphasis for the characterization was given in the percentage of core stones in the material. Karpuz and Pasamehmetoglu (1997), who studied Ankara andesites, proposed an idealized weathering profile and scale of rock mass weathering with their range of thicknesses. They recommended that weathering grades of this acidic volcanic rock could be quantified by means of both index and field tests.

\begin{tabular}{|c|c|c|c|c|c|c|}
\hline \multirow{3}{*}{ Weathering indicator } & \multicolumn{4}{|c|}{ Rock } & \multicolumn{2}{|c|}{ Soil } \\
\hline & \multicolumn{6}{|c|}{ Weathering grade } \\
\hline & I & II & III & IV & V & VI \\
\hline \multicolumn{7}{|l|}{ Discoloration } \\
\hline Rock/soil ratio & \multicolumn{3}{|c|}{$>50 \%$} & \multicolumn{3}{|c|}{$<50 \%$} \\
\hline \multicolumn{7}{|l|}{$\begin{array}{l}\text { Corestones and } \\
\text { relict structures }\end{array}$} \\
\hline $\begin{array}{l}\text { Discontinuity spacing } \\
\text { for fracture frequency }\end{array}$ & & & & & \multicolumn{2}{|c|}{ Not applicable } \\
\hline \multicolumn{7}{|l|}{ Mineralogy } \\
\hline $\mathrm{RQD}$ & & & & & \multicolumn{2}{|c|}{ Not applicable } \\
\hline SHV & $>50$ & $40-50$ & $30-40$ & $<30$ & \multicolumn{2}{|c|}{ Not applicable } \\
\hline
\end{tabular}

Clearly different - - Sometimes difficult to differ

Tab. 1. Field indicators for the characterization of volcanic rocks (from Arikan et al., 2007 with additions from present study)

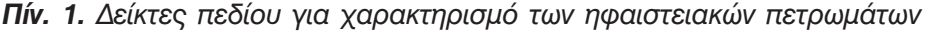

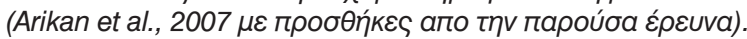

Arikan et al. (2007) proposed a weathering classification for acidic volcanic rocks based on a rating system. They presented a comparison of some field indicators to recognize the weathering grades of andesites and dacites, as presented in Tab. 1. The system consisted of six (6) grades ranging between fresh rock (grade I) and residual soil (grade VI). The rocks studied have been affected by hydrothermal alteration and weathering. For this rating, they have used the uniaxial strength, the tensile strength, the longitudinal wave velocity and the block punch strength index for the grades I to IV which refer to rock. The values of these parameters decreased from grades I to IV indicating that the strength of volcanic rocks is significantly influenced by the change in the character of the material due to weathering.

Finally, their characterization has taken into account the rock/soil ratio to distinguish between soil and rock behaviour of the volcanic rock and Schmidt hammer values (for grades I to IV). They proposed that a moderately weathered formation has a rock/soil ratio greater than 50\% and Schmidt hammer values greater than 30 . For highly weathered formations, the rock/soil ratio is lower than $50 \%$ and Schmidt hammer values lower than 30 . In Completely weathered rocks (grade V), corestones may be present resulting in a rock/soil ratio is lower than 20 to $30 \%$. 


\subsection{Slope instabilities in volcanic formations}

The types of instabilities encountered in volcanic formations are primarily the following, according to the classification proposed by Varnes (1978):

1. Rockfalls and toppling failures when the formations have a rock structure

2. Rotational and translational soil failures,

3. Lateral spreading when hard rock formations overlie weak, totally weathered volcanic formations

4. Creep and earth flows in weak, argillaceous formations.

5. Composite failures when mixed rock and soil formations exist,

Slopes in volcanic formations have a complex behaviour, which primarily depends on the existence of interlayers of sedimentary rocks and their degree of weathering or hydrothermal alteration. When these are encountered interbedded with sedimentary rocks, the form of instabilities is governed by the geometry of the weak layers and the nature of the interbedded formations. Instabilities are planar - translational along weak layers or composite. When no interbeds exist, the controlling factor is the engineering behaviour of the volcanic formations which may range from soil to rock, depending on the degree of weathering and hydrothermal alteration (if present). Thus, if the formation has a rock structure, instabilities are controlled by the nature and orientation of discontinuities and their properties. The usual forms of instability are kinematical falls (planar, wedge and toppling failures) as well as rockfalls. When the volcanic formations are highly to totally weathered, usually clay rich soil formations are evident and slope instabilities in the form of rotational failures exist. Since weathered volcanic rocks and tuffs can produce block-in-matrix formations the block proportion in the soil mass can influence the geometry of the failure surface as it may be impeded by blocks (Medley and Sanz Rehermann, 2004; Tsiambaos, 2010).

\section{Volcanic Formations in Lesvos Island \\ 2.1. General}

The study area is located in the Northern part of Lesvos Island, in Petra prefecture. Two areas were examined, characterized by different engineering geological behaviour of the volcanic rocks. In area 1 a slightly weathered andesite is encountered, which has a rock type behavior, while in area 2 volcanic tuffs and totally weathered andesites (clay rich kaolinitic soils), having a soil type behavior are found. The present study analyses the different mechanism of the instability phenomena originating from the different nature (rock or soil) of these volcanic formations.

\subsection{Geological setting - hydrogeology} Geologically the northern part of Lesvos island consists of andesite-dacite lavas, $400 \mathrm{~m}$ thick (Hecht, 1974; Pe-Piper, 1978). The fresh parts of the rocks are strong but in the upper parrt the materials are weathered and loose. The main geological formations, which were encountered in the area are (as presented in Fig. 1, based on the present study and the geological map by Hecht, 1974): (a) lateral scree (H.cs), (b) allouvial deposits (fine and coarse grained), (c) silicated lavas (Ng.q), (d) rhyodacitic veins (Ng.d), (e) rhyodacitic, latitic, latiandesitic lavas of the upper lava group (Ng.ul) (f) latiandesitic lavas of the lower lava group ( $\mathrm{Ng}$. II2), (g) pyroclastic formation - lapilic tuff (Ng.pc). At the base of the upper lava group, numerous kaolinitized zones exist. 
The mineralogical composition of the andesites is reported as a microfelsitic mass made from a mixture of feldspar material, hematite and quartz in small percentage. The phenocrystalls include plagioclase, pyroxene, biotite and alteration products are olivine, talc, clay minerals from feldspars and mixture of metals (magnetite, feroxide).

The lavas have generally a rock like nature while the tuffs and weathered "kaolinitized" zones have a soil like nature. The area is intersected by a number of faults, which have a WNW-ESE and NESW strike.
These are responsible for the creation of the tectonic graben of Petra. The study area belongs to the geothermal field of Stypsi, which is affected by significant hydrothermal activity. The area is characterized by the presence of the contact zone between the upper and lower lava units, which for a significant length is through fault structures (Fig. 1). Concerning the hydrolithological behaviour of the geological formations the upper lava unit has medium permeability with medium infiltration capacity while the lower lava unit and the tuff formation are relatively impermeable with low infiltration.
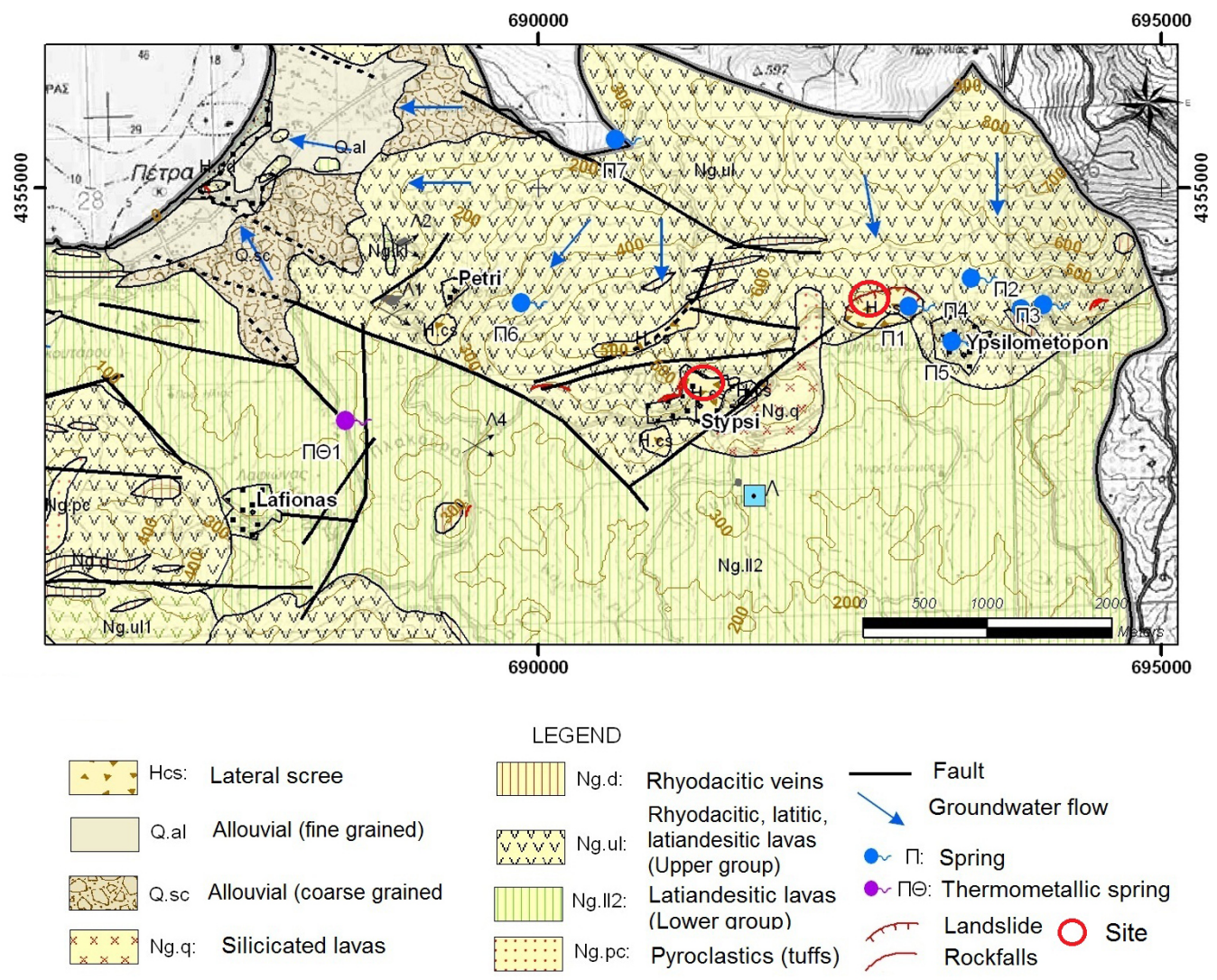

Fig. 1. Geological map of the study area.

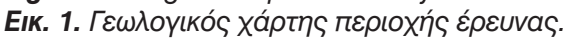




\subsection{Instability phenomena}

\subsubsection{Types of instabilities}

The broader study area is characterized by different types of instabilities in rock and soil formations. More specifically, in the dacitic and andesitic lavas rockfalls and failures along discontinuities occur. Rotational or translational slides, which are small in scale have occurred in the totally weathered andesites, residual soils, silicated lavas, pyroclastics (tuffs).

Instabilities in loose volcanic formations in the form of landslides in Lesvos Island have been reported by Christaras et al. (2000).

\subsubsection{Rock type failures}

Characteristic rock failures in the form of rockfalls are encountered in the village of Stypsi (Fig. 2) and the protruding rock tower in the city of Petra, where the monastery Koimisi of Theotokos is founded. Toppling failures are encountered along the national road near the village of Ipsilometopo, where andesitic lavas with vertical cooling joints outcrop (Fig. 3).

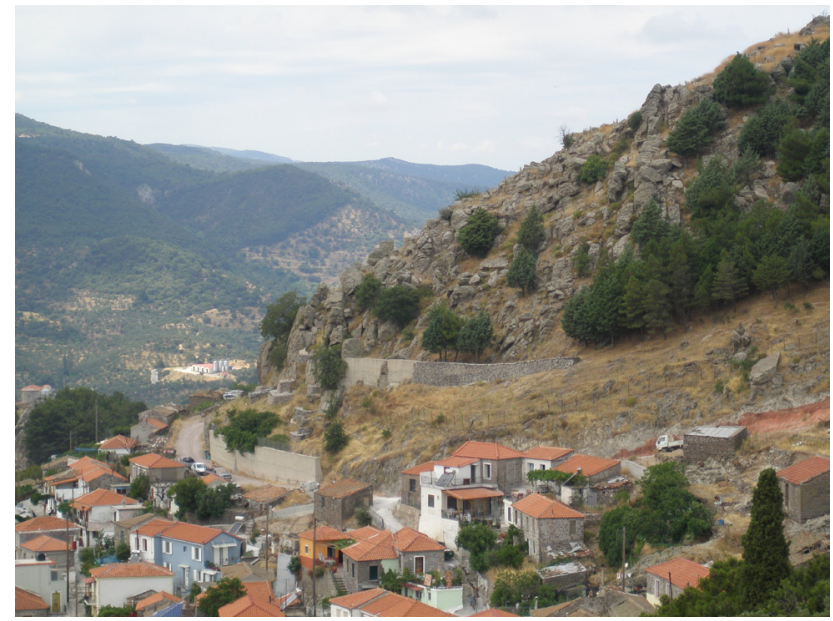

Fig. 2. Rock slope overhanging the village of Stypsi where rockfalls have occurred.

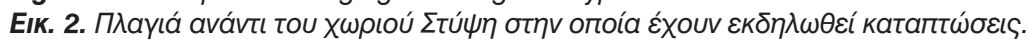

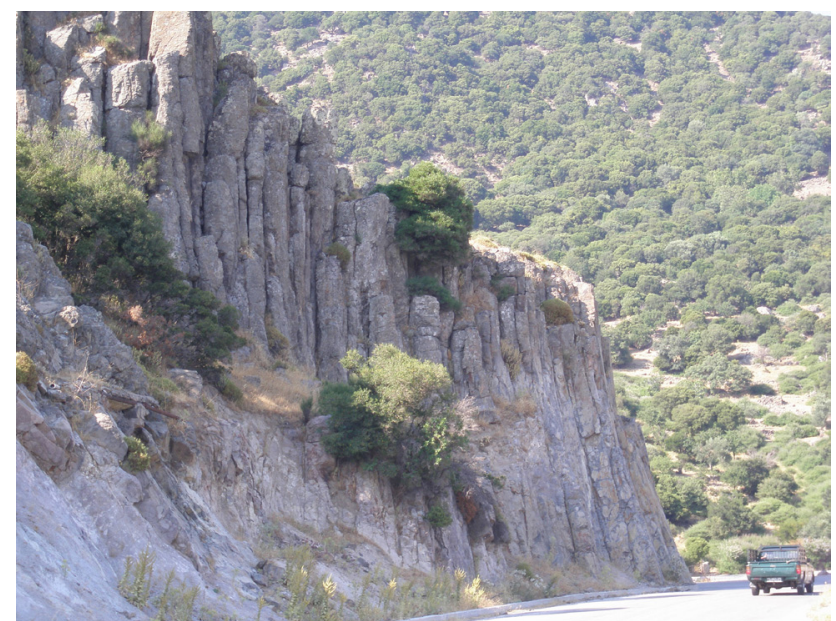

Fig. 3. Slope in andesitic lavas, prone to toppling failure.

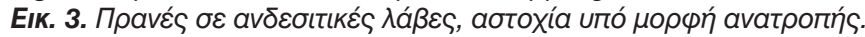




\subsubsection{Soil type failures}

As stated earlier, soil instabilities in the broader area are found in the weathered profiles of lavas and pyroclastic formations. Such a landslide occurred in the study area (near Stypsi village in December 1968 in the tuff and the weathered upper parts of the andesitic formations, which are practically clay soil formations with some rock blocks (Fig. 4). The slide caused a movement over a length of 60 $\mathrm{m}$, with a vertical displacement of $1.0 \mathrm{~m}$ at the national road. The landslide had an area of 5 acres as reported by Katsikatsos (1969). The slope where the landslide occurred has an angle of 20$22^{\circ}$ dipping to SE. The area of the slide consist of pyroclastic tuffs and totally weathered andesites, having a high per- centage of clay minerals (Fig. 5). These are overlain by massive andesite rocks of the upper lava unit, which due to their fracturing, result in the formation of contact springs along their base. Along the slipped area, springs are encountered until today with generally low outflow (3 $-5 \mathrm{~m}^{3} / \mathrm{h}$ ).

The factors that triggered the landslide were: a) the high percentage of clay materials, b) the underground and surface flow of water from springs and c) the high slope angle in certain locations. The mineralogical composition of the kaolinitic formations in the area of Stypsi is: kaolinite (19\%), saponite (8\%), montmorillonite (4\%), illite (25\%), quartz $(31 \%)$, albite $(4 \%)$, others $(9 \%)$ (Tsoli Kataga, 1979).

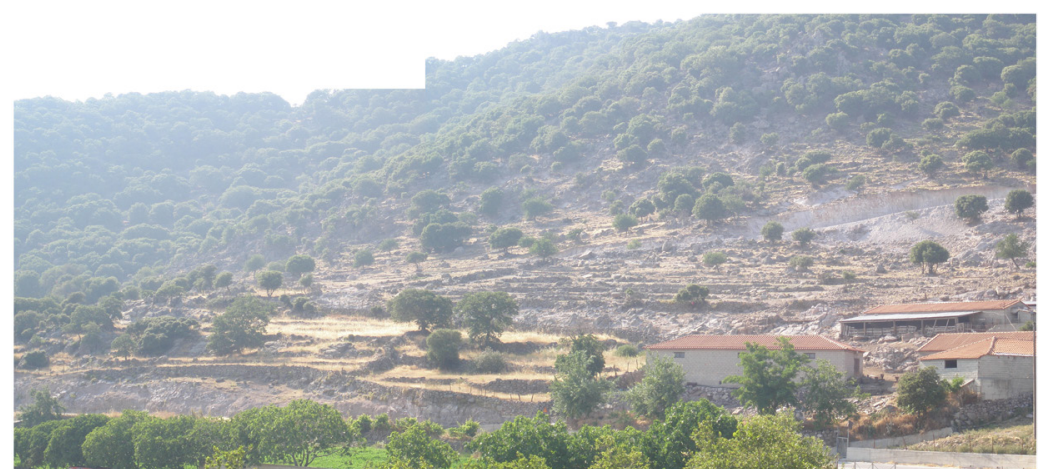

Fig. 4. Area with instability phenomena in tuffs and extremely weathered andesites.

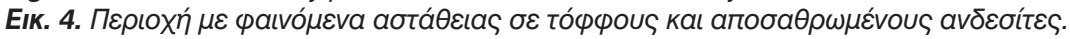

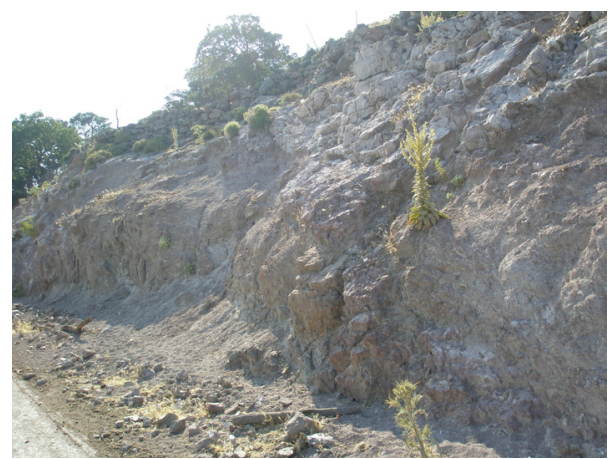

Fig. 5. Close view of tuffs and extremely weathered andesites in the site of the examined slope failure.

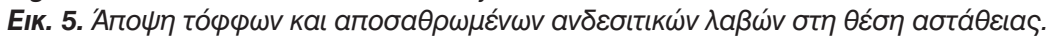




\subsection{Engineering geological behaviour}

The weathering state of the formations, encountered in the two study areas, were distinguished in the field (at both the material and mass scale) based on an assessment of the degree of discoloration of the rock material, the presence of the original rock texture/fabric or structure and rock-soil ratio as suggested by ISRM (1981). In addition to these visual descriptions, Schmidt hammer rebound values (SHV) were obtained for the andesites in area 1 (which retains a rock structure). Finally the materials were characterized according to the weathering rating proposed by Arikan et al. (2007). The results are presented in Tab. 2.

The point load strength of the andesites in area 1 (for weathering grade II) was found equal to $2.7 \mathrm{MPa}$, having a range between 0.5 and $6.7 \mathrm{MPa}$. The uniaxial compressive strength was found equal to $54 \mathrm{MPa}$.

In area 2, the weathering grade of the tuffs and andesites is $\mathrm{V}$ to $\mathrm{VI}$ having a soil like behavior. The original structure of the andesitic rock is retained in very few places, in the form of small corestones within the clay soil mass (Fig. 5).

\section{Slope Stability}

\subsection{Rockfall case study}

The rockfall case study in area 1 refers an andesitic slope overhanging the village of Stypsi. Andronopoulos \& Koukis (IGME, 1979) have performed a detailed study in the broader area after the rockfall events that occurred in 1977. In this study, they described the rock structure of the andesitic rockmass and the rockfall instability mechanisms in detail, while they also proposed a number of stabilization measures. Additionally, a detailed stabilization study was carried out for the protection of the village from rockfalls (Pangea, 1995; Apostolidis, 2002).

The andesitic rockmass is intersected by three main discontinuity sets, one of which is the pseudo-bedding of the lavas. The dip of the discontinuities ranges between 50 and 80 degrees. The average slope angle is $50^{\circ}$, while locally it can reach up to $80^{\circ}$ due to the relaxation of the andesitic rock mass and formation of steep cuts parallel to the almost vertical joint sets. Extensive rockfalls have occurred in the past (in 1963 and 1977), posing a significant hazard for the houses and human activities of the village. The size of the potentially unstable blocks range between 0.5 and $3.0 \mathrm{~m}^{3}$, and the average size is $1.0 \mathrm{~m}^{3}$. The detachment of the blocks can occur from different heights above the village and can reach $40 \mathrm{~m}$ approximately.

\begin{tabular}{|c|c|c|c|c|}
\hline Characterization & \multicolumn{3}{|c|}{ Area 1} & Area 2 \\
\hline Description & \multicolumn{3}{|c|}{$\begin{array}{l}\text { Slightly to moderately } \\
\text { weathered andesite, } \\
\text { intersected by three joint sets }\end{array}$} & $\begin{array}{l}\text { Tuffs and totally weathered } \\
\text { andesites resulting in clay } \\
\text { rich soils }\end{array}$ \\
\hline Rock/Soil Ratio (\%) & \multicolumn{3}{|c|}{$>80$} & $<20$ \\
\hline SHV & 51 & 45 & 34 & - \\
\hline Weathering Grade & I & II & III & $\mathrm{V}$ to $\mathrm{VI}$ \\
\hline
\end{tabular}

Tab. 2. Weathering grade of encountered materials in the study areas

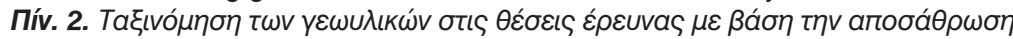


A rockfall analysis was performed in order to study the phenomenon using Rocfall software (Rocscience Ltd.). The slope section for the analysis was taken from Andronopoulos and Koukis (1979). The coefficients of restitution of the andesites were considered equal to $R n=0.63$ and $R t=0.85$, based on relevant experience (Richards et. al., 2001). The analysis was performed, considering different heights of the detachment of the rocks (ranging between 9 and $40 \mathrm{~m}$ ). Additionally, since the normal coefficient decreases with the increase of weathering, a set of analysis were carried out using different weathering grades of the rock slope. Saroglou et. al. (2010) have proposed a correlation between the normal coefficient of restitution, $\mathrm{Rn}$, and the Schmidt hammer value, described by the equation $\mathrm{Rn}=0.0086 * \mathrm{SHV}+0.19$. Based on the Schmidt hammer values shown in Tab. 2, the coefficient was reduced as the weathering grade increased. More specifically, $R n$ was calculated equal to 0.58 for weathering grade II and 0.48 for grade III. The tangential coefficient is less dependant on the hardness of the bouncing surface, therefore it was only reduced from 0.85 to 0.80 . The friction angle was reduced from 32 to 30 degrees. No initial velocity of the falling rocks was considered. The resulting kinetic energy at the slope foot (at the upper end of the village) was found to increase substantially with the height of the detachment point, while it reduced significantly with increasing weathering degree, as shown in Fig. 7.

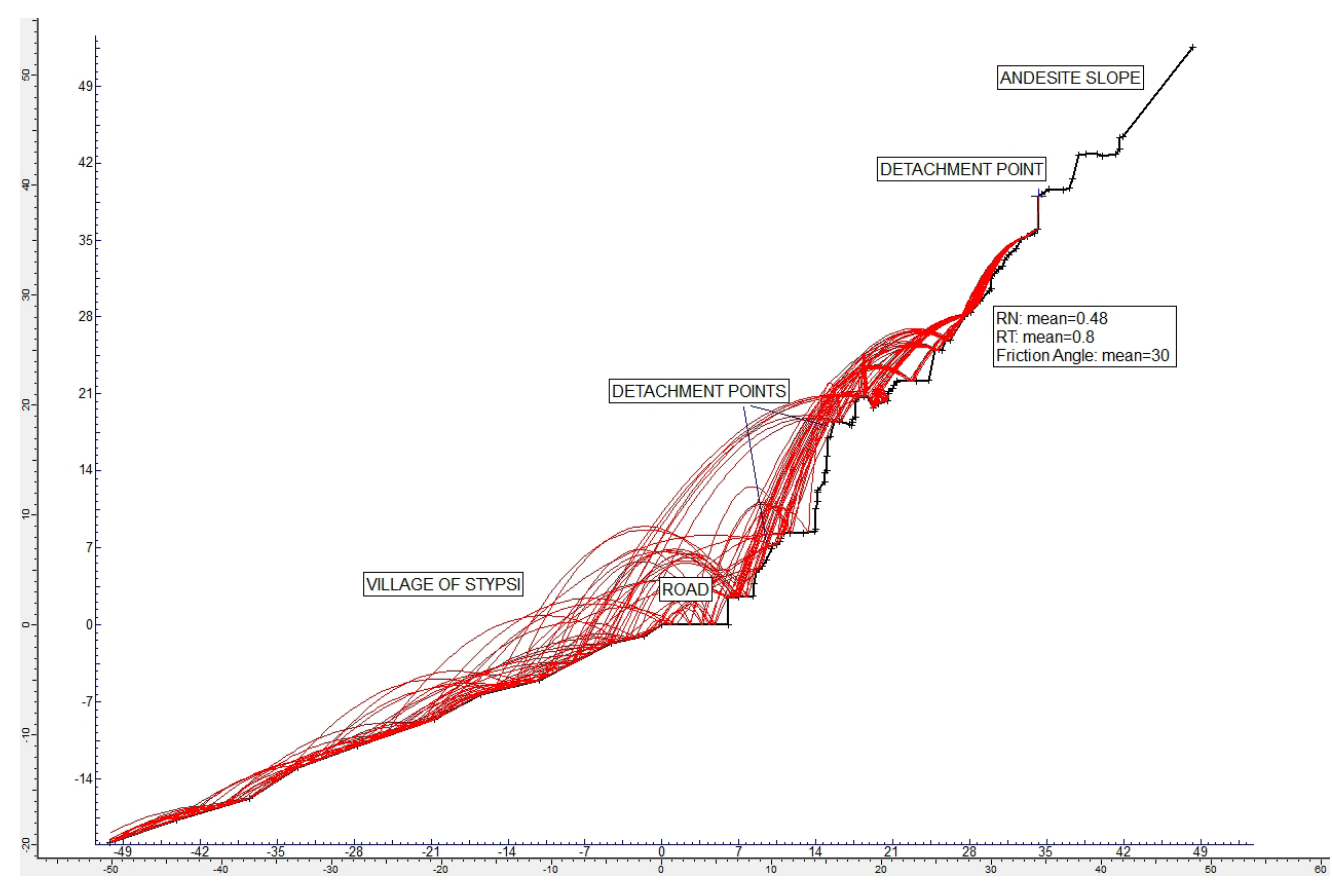

Fig. 6. Rockfall analysis for the slope of Stypsi village.

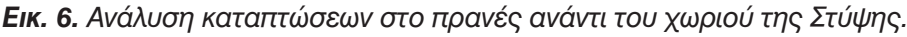




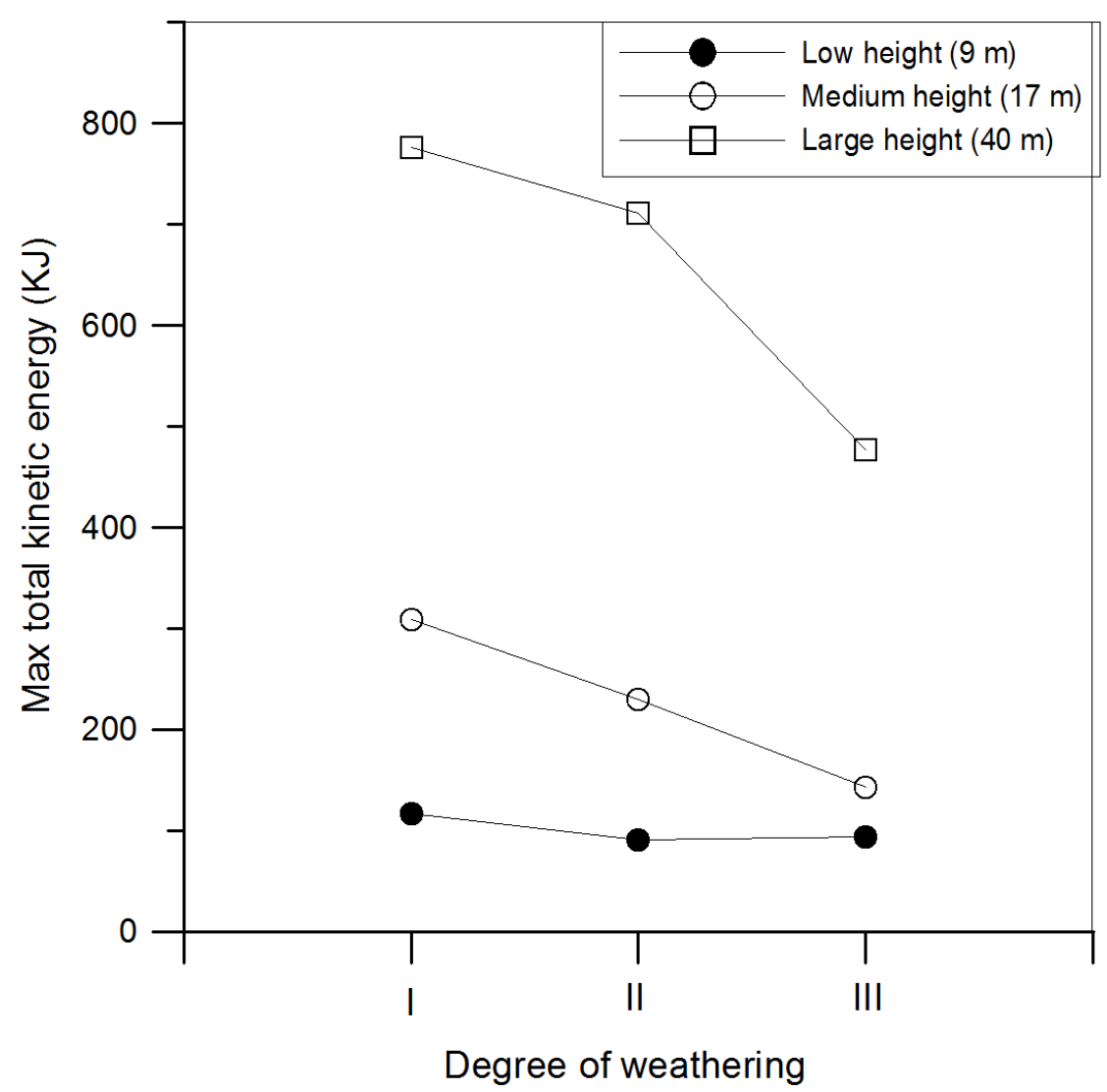

Fig. 7. Variation of maximum total kinetic energy related to weathering degree

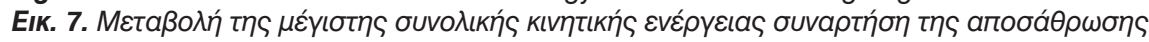

The rock slope has been stabilized at certain locations, following the rockfall events in 1963 and 1977 by the erection of concrete and stonewalls on the slope for the closure of cavities and support of overhanging andesite blocks. Other stabilization measures include construction of a concrete wall - barrier at the slope foot for a limited length, installation of wire mesh and cables at selected locations, planting of vegetation for the restrain of falling rocks and filling of open joints with cement for strengthening of the rockmass (as reported in Apostolidis, 2002).
The erection of rockfall barriers along the slope foot would further reduce the rockfall risk on human activities in the area.

\subsection{Rotational slide}

Based on the geometry of the slipped mass a slope stability analysis was performed, in order to define the sliding mechanism. The properties of the tuffs weathered materials were taken from literature (del Potro and Hürlimann, 2009; Rodriguez Pineda, 2007), considering a clay rich soil. The increase of the rock/ soil percentage within the slipped mass 
(up to $30-40 \%$ ), which could occur in tuffs and weathered ground profiles, would result in a higher overall strength of the material. Medley and Sanz Rehermann (2004) have proposed a slope stability approach, which is based on the mechanism of failure of block-in-matrix formations. This approach assumes that failure does not occur only through the soil but also can be influenced by the presence of rock blocks in the soil mass. It requires the calculation of the equivalent strength of the block-in-matrix formation, by taking into account the strength of the rock blocks and the surrounding soil mass in the relevant proportions. This approach was not taken into account in the present study.

The slope stability assumed that sliding took place through a soil material (tuff and totally weathered andesite), having a thickness of $15 \mathrm{~m}$. The peak strength of the clay rich soil was taken equal to $c^{\prime}=10 \mathrm{kPa}$ and $\varphi=21^{\circ}$, while the strength of the underlying and overlying andesitic formations (lower and upper unit) equal to $c=80 \mathrm{kPa}$ and $\varphi=35^{\circ}$. The level of the water table was considered to lie 2 $\mathrm{m}$ below ground water surface, due to the presence of flowing water from the springs in the area.

The stability analysis was performed verifying that the geometry of the sliding surface coincides with the field observations and description given by Katsikatsos (1969). The analysis was performed with Slide software (Rocscience Ltd.).

The factor of safety for saturated conditions was calculated equal to 1.17 (as shown in Fig. 8), while for drained conditions it was found equal to 1.89 . This implies that failure occurred under undrained conditions. The factor of safety under seismic loading was calculated equal to 1.25. It was also investigated that if the slide occurred at lower elevation the factor of safety would be slightly higher due to the lower slope angle.

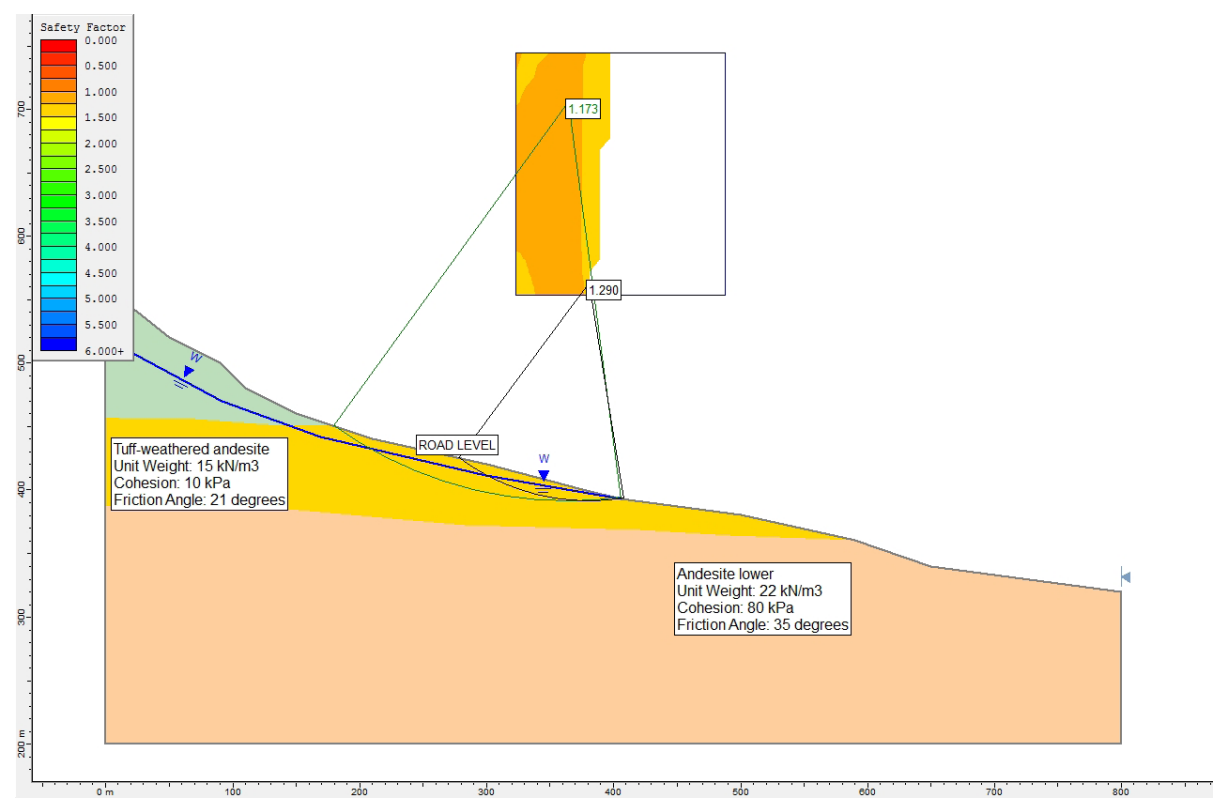

Fig. 8. Slope stability analysis at the landslide site of a slope near Stypsi village.

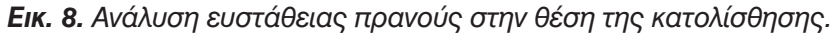




\section{Vulnerability Map for Instabilities - Town Planning}

\subsection{Criteria}

A simple zonation of the area against instability phenomena is proposed based on the following factors: a) slope aspect and b) geological nature of the volcanic formations. Concerning the geological nature, the degree of weathering and permeability is taken into account. The intensity of rainfall and the presence of groundwater are important when assessing the possibility of occurrence of slope instabilities. The effect of groundwater was taken into consideration indirectly in the overall assessment of the geological behaviour of the formations. Rainfall intensity remains the same for the study area and thus it was not taken into account.

The geological formations, which will result in rock instabilities, are the andesites of the upper and lower lava unit, with weathering degree between I and IV. The geological formations prone to soil type instabilities are the totally weathered an- desites with weathering degree between $\mathrm{V}$ and VI, the pyroclastic formations (tuffs) and the silicated lavas. These formations have a soil-like behaviour.

The slope inclination is important since it can determine the depth of the weathering profile but also is directly related to the outbreak of instability, as analyzed in the following paragraph.

Furthermore,

\subsection{Vulnerability Map}

When studying slope instability in terms of zonation, it is important to define slope inclination classes. For the purpose of this study a simple approach was considered. Areas with a slope angle greater than 35\% (20 degrees) were designated as potential for the outbreak of instabilities (either soil or rock type). The slope aspect map of the area (Fig. 9) shows that a significant part of the study area has slope inclination greater than $40 \%$. Additionally, there is also a large area where the morphology is gentle with slope inclinations lower than 150 .
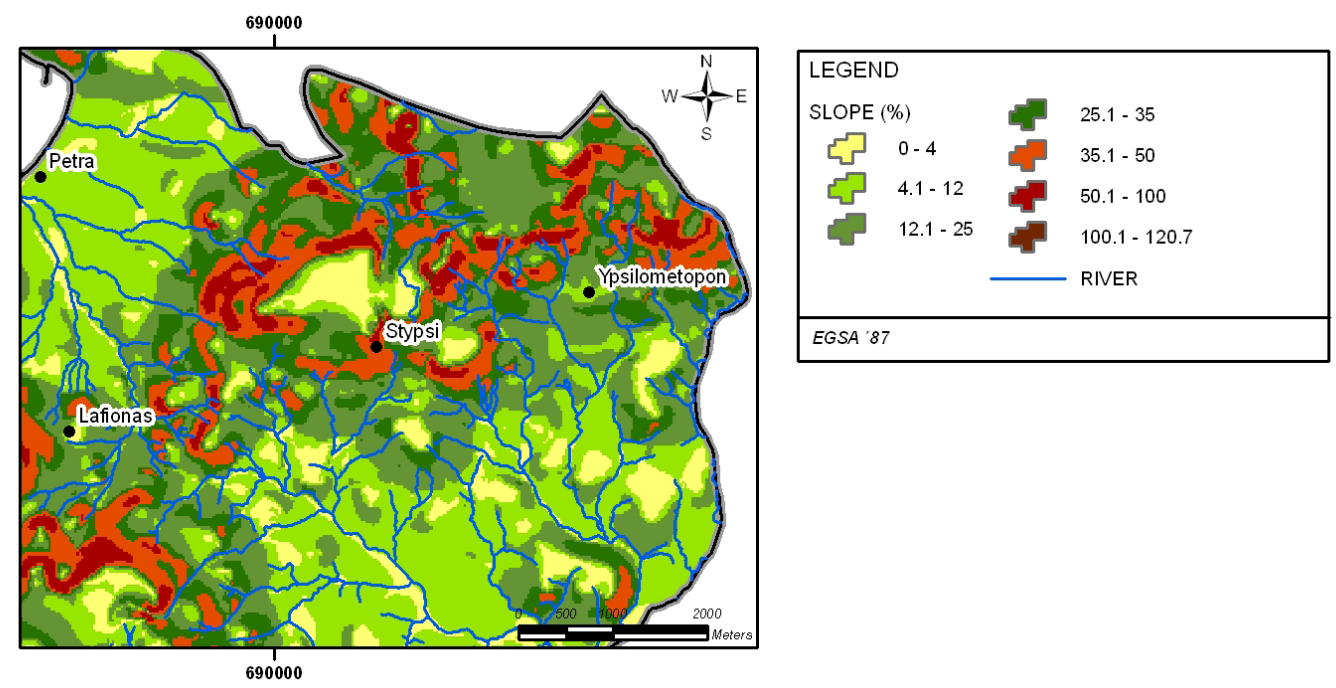

Fig. 9. Slope aspect map of the study area.

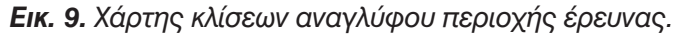


Based on the criteria presented earlier, a vulnerability map against instabilities was prepared for the study area. The categories, which were attributed, are the following:

a) Area prone to rockfalls

b) Area prone to soil instabilities

c) Reasonably stable areas.

The map is presented in Fig. 10. It must be stated that the totally weathered zones of the andesites as well as the kaolinitized zones of the volcanic formations cannot be outlined accurately in this scale. For this purpose, such a vulnerability map should be used for information purposes only.

\section{Conclusions}

The engineering geological behaviour of volcanic formations was reviewed based on references from literature. The behaviour varies significantly between soil and rock depending primarily on the geological origin and weathering degree. A weathering classification of volcanic formations was presented and applied to the analysis of slope instability phenomena encountered in andesitic formations in Lesvos Island in Greece. The slope instabilities in the two case studies, which were analyzed were representative of the different geological behaviour, either soil or rock. In the rockfall case, the effect of

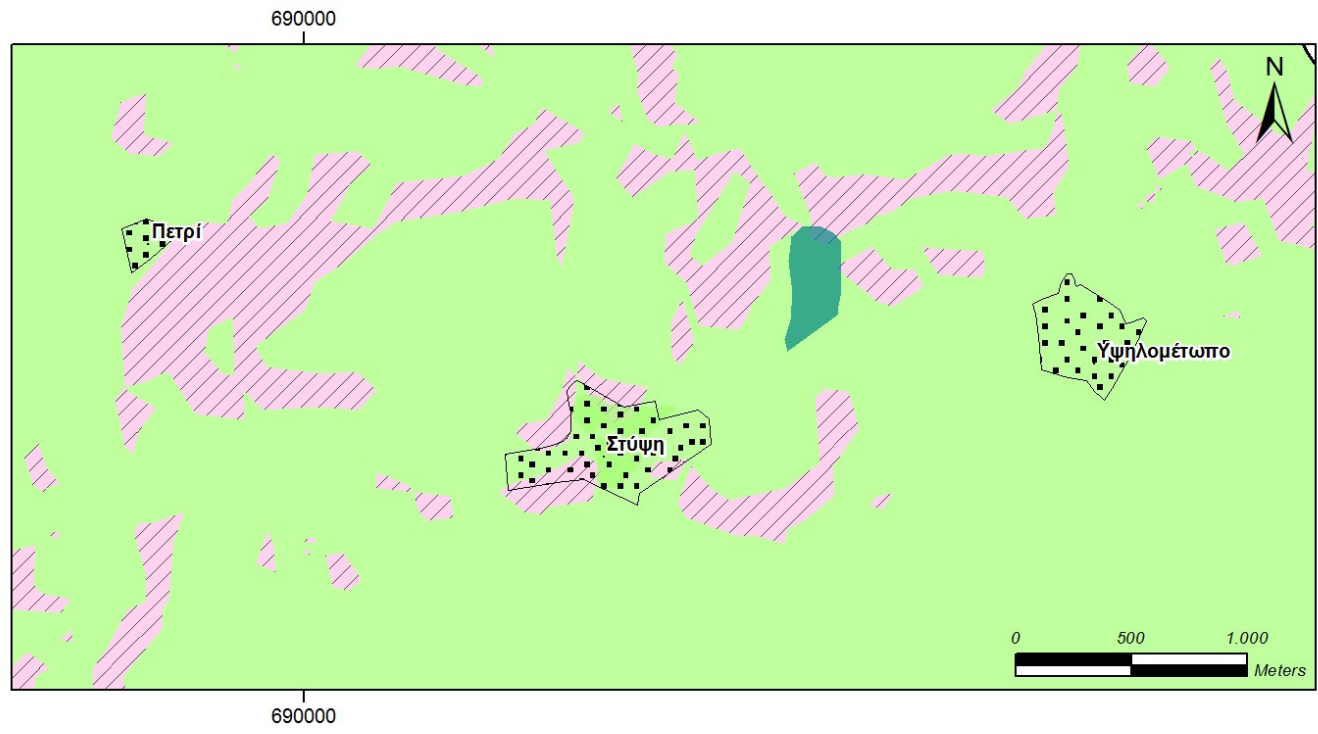

LEGEND

Fig. 10. Vulnerability map of the study area, regarding the slope Instability.

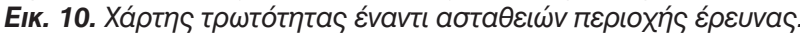


weathering of the andesitic rock on the kinetic energy of the falling rocks was examined. For this purpose, the use of Schmidt hardness values was utilized in order to characterize the weathering degree of the slope on which rockfalls occurred. In the second case, a rotational soil instability in a tuff and totally weathered andesite formation was analyzed. The slope stability of volcanic rocks, which have a soil like behaviour, can be analyzed by either considering geotechnical parameters for a soil mass or the equivalent ones for a soil mass having blocks of rock inside it (block-in-matrix formation).

Finally, a simple zonation of the study area against instability phenomena was proposed based on the slope aspect and the geological nature of the volcanic formations encountered.

\section{Aknowledgements}

The assistance of E. Lykoudi, Geologist $\mathrm{PhD}$ in the preparation of maps is greatly acknowledged.

\section{References}

Arıkan, F., Ulusay, R., Aydın, N., 2007. Characterization of weathered acidic volcanic rocks and a weathering classification based on a rating system. Bull Eng Geol Environ 66, 415-430.

Christaras, B., Zouros, N. Marinos, P., 2000. Heavy rains and mass movements in loose volcanic formations. Examples from Sarno (Italy) and Lesvos island (Greece). International Conference on Geotechnical \& Geological Engineering (Geoeng2000), Melbourne, in CD.

Del Potro, R., Hürlimann, M., 2009. The decrease in the shear strength of volcanic materials with argillic hydrothermal alteration, insights from the summit region of Teide stratovolcano,
Tenerife. Engineering Geology 104, 135-143.

Hecht, J., 1974. Geological map of Greece, scale 1:50.000 (Sheet Mythimna) I.G.M.E.

Andronopoulos, B., Koukis, G., 1979. Geological, Microtectonic and Geotechnical Study in the NW part of the Lesvos Island. I.G.M.E.. Engineering Geology Investigations No. 8, 41 p. [in Greek].

Apostolidis, E., 2002. Engineering Geological investigation of the instability phenomena in Stypsi, Petra prefecture, Lesvos Island. I.G.M.E., 37 p. [in Greek].

Irfan, T.Y., 1999. Characterization of weathered volcanic rocks in Hong Kong. Q J Eng Geol 32, 317-348.

ISRM, 1981. In: Brown, E.T. (Ed), Rock characterization, testing and monitoring-ISRM suggested methods. Pergamon Press, Oxford, 211pp.

Karpuz, C, Pasamehmetoglu, A.G., 1997. Field characterization of weathered Ankara andesites. Eng Geol 46, 1-17.

Katsikatsos, G., 1969. Report on the landslide, which occurred between Stypsi and Ypsilometopo villages, Lesvos Island. I.G.M.E., 4 p. [in Greek].

Medley, E., Sanz Rehermann, P., 2004. Characterization of Bimrocks (Rock/ Soil Mixtures) with application to slope stability problems. Eurock $2004 \& 53^{\text {rd }}$ Geomechanics Colloquium, Salzburg, Austria.

Pangaia Consulting Engineers, 1994. Study for the protection of Stypsi village from rockfalls.

Pe - Piper, G., 1978. The Cenozoic volcanic rocks of Lesvos island. Ph.D. Thesis. University of Patras.

Richards, L.R., Peng, B., Bell, D.H., 2001. Laboratory and field evaluation of the normal coefficient of restitution for rocks. Int. Symposium Rock Mechan- 
ics- a challenge for society, 149.

Rodriguez Pineda, C. E., 2007. Landslides On Volcanic Soils: A Case History. International Symposium on Landslide Risk Analysis and Sustainable Disaster Management (IPL 2007), Tokyo, 91.

Saito, T., 1981. Variation of physical properties of igneous rocks in weathering. International symposium on weak rocks, Tokyo, 191.

Saroglou, H., Mpekri, E., Tsiambaos, G., 2010. Determination of critical geotechnical parameters of geological formations for the modeling of rockfalls in slopes. $6^{\text {th }}$ Hellenic Conf. of Geotechnical and Geoenvironmental Engineering, Volos. 43.

Tsiambaos, G., 2010. Engineering geological behaviour of heterogeneous and chaotic rock masses". 12 $12^{\text {th }}$ Int. Congress, Bull. of the Geological Society of Greece, 183.

Tsoli - Kataga P., 1979. Geological, mineralogical and geochemical study of the Lesvos kaolinites. Ph.D. Thesis, University of Patras.

Tugrul, A.,, Gurpinar, O., 1997. A proposed weathering classification for basalts and their engineering properties (Turkey). Bull Eng Geol Environ, 55, 139-149.

Varnes, D.J., 1978. Slope movement, types and processes. In: Schuster, R.L., Krizek, R.J. (Eds), Landslides Analysis and Control. Schuster, R.L. and Krizek, R.J. (Eds.), National Academy of Science, Report 176, Washington, DC, 11-35. 